DEPARTMENT OF THE INTERIOR

ALBERT B. FALL, SECRETARY

NATIONAL PARK SERVICE

STEPHEN T. MATHER, DIRECTOR

\title{
FOSSIL FORESTS OF THE YELLOWSTONE NATIONAL PARK
}

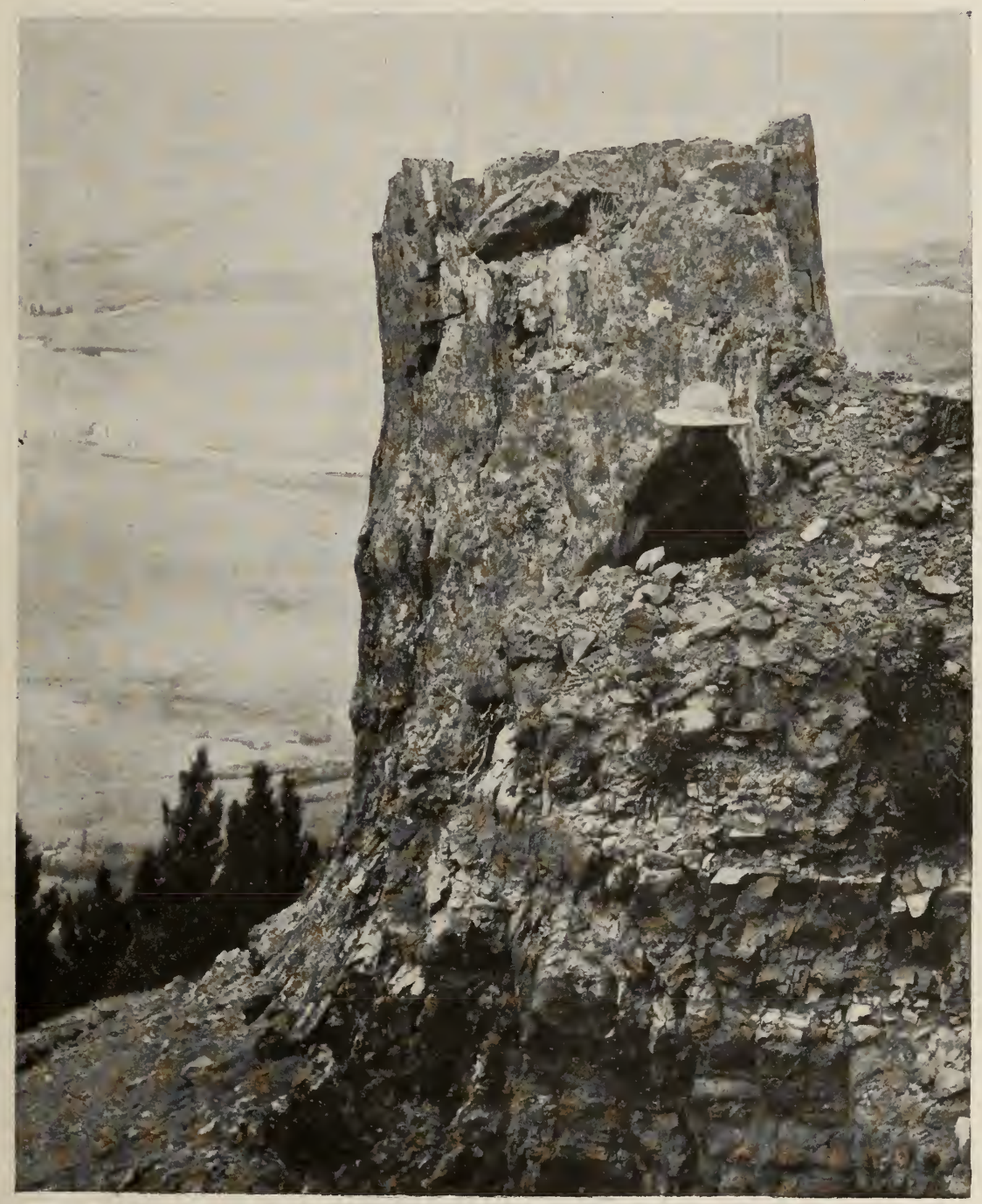

WASHINGTON

GOVERNMENT PRINTING OFFICE 


\section{THE NATIONAL PARKS AT A GLANCE.}

[Number, 19; total area, 10,859 square miles.]

\begin{tabular}{|c|c|c|c|}
\hline $\begin{array}{l}\text { Nati } \\
\text { ord }\end{array}$ & Location. & $\begin{array}{l}\text { Area in } \\
\text { square } \\
\text { miles. }\end{array}$ & Distinctive characteristics. \\
\hline Hot Springs. . & Middle Arkansas.... & $I_{2}^{\frac{1}{2}}$ & $\begin{array}{l}46 \text { hot springs possessing curative properties- } \\
\text { Many hotels and boarding houses-20 bath- } \\
\text { houses under public control. }\end{array}$ \\
\hline$\underset{1872}{\text { Yellowstone. }}$ & $\begin{array}{l}\text { Northwestern Wyo- } \\
\text { ming. }\end{array}$ & 3,348 & $\begin{array}{l}\text { More geysers than in all rest of world together- } \\
\text { Boiling springs-Mud volcanoes-Petrified } \\
\text { forests-Grand Canyon of the Yellowstone, re- } \\
\text { markable for gorgeous coloring-Large lakes- } \\
\text { Many I arge streams and waterfalls-Vast wil- } \\
\text { derness, greatest wild bird and anima lpreserve } \\
\text { in world-Exceptional trout fishing. }\end{array}$ \\
\hline $\begin{array}{r}\text { Sequoia ....... } \\
\text { I } 890\end{array}$ & $\begin{array}{l}\text { Middle eastern Cali- } \\
\text { fornia. }\end{array}$ & 252 & $\begin{array}{l}\text { The Big Tree National Park-I } 2,000 \text { sequoia trees } \\
\text { over Io f eet i n diameter, some } 25 \text { to } 36 \text { f eet in } \\
\text { diameter-Towering mountain ranges-Start- } \\
\text { ling precipices-Cave of considerable size. }\end{array}$ \\
\hline 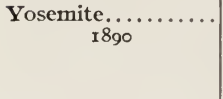 & $\begin{array}{l}\text { Middle eastern Cali- } \\
\text { fornia. }\end{array}$ & I, I 25 & $\begin{array}{l}\text { Valley of world-famed beauty-Lofty cliffs- } \\
\text { Romantic vistas-Many waterfalls of extraor- } \\
\text { dinary height-3 groves of big trees-High } \\
\text { Sierra-Waterwheel falls-Good trout fishing. }\end{array}$ \\
\hline$\underset{1890}{\underset{1}{\text { General Grant... }}}$ & $\begin{array}{l}\text { Middle eastern Cali- } \\
\text { fornia. }\end{array}$ & 4 & $\begin{array}{l}\text { Created to preserve the celebrated General Grant } \\
\text { Tree, } 35 \text { feet in diameter }-6 \text { miles fom Sequoia } \\
\text { National Park. }\end{array}$ \\
\hline $\begin{array}{r}\text { Mount Raini } \\
\text { I899 }\end{array}$ & $\begin{array}{l}\text { West central Wash- } \\
\text { ington. }\end{array}$ & 324 & $\begin{array}{l}\text { Largest accessible single peak glacier systcm-28 } \\
\text { glaciers, some of large size } 48 \text { square miles or } \\
\text { glacier, } 50 \text { to } 500 \text { i cet thick-Wonderful sub- } \\
\text { alpine wild flower fields. }\end{array}$ \\
\hline $\begin{array}{l}\text { Crater Lake.. } \\
1902\end{array}$ & Southwestern Oregon. & 249 & $\begin{array}{l}\text { Lake of extraordinary blue in crater of extinct } \\
\text { volcano-Sides I, ooo feet high-Interesting lava } \\
\text { formations-Finc fishing. }\end{array}$ \\
\hline$\underset{1903}{\text { Wind Cave. }}$ & South Dakota.. & $x_{7}$ & $\begin{array}{l}\text { Cavern having many milc } \\
\text { ous chambers containin }\end{array}$ \\
\hline Platt....... & Southern Oklahoma.. & $I_{3}^{1}$ & $\begin{array}{l}\text { Many sulphurand other springs possessing medic- } \\
\text { i nal value. }\end{array}$ \\
\hline $\begin{array}{r}\text { Sullys Hill... } \\
\text { I904 }\end{array}$ & North Dakota. & $\mathbf{I}_{5}^{\frac{1}{5}}$ & $\begin{array}{l}\text { Small park with woods, streams, and a lake-Is } \\
\text { an important wild animal preserve. }\end{array}$ \\
\hline $\begin{array}{r}\text { Mesa Verde... } \\
\text { I906 }\end{array}$ & $\begin{array}{l}\text { Southwestern Colo- } \\
\text { rado. }\end{array}$ & 77 & $\begin{array}{l}\text { Most notable and best preserved prehistoric cliff } \\
\text { dwellings in United States, if not in the world. }\end{array}$ \\
\hline Glacier..... & $\begin{array}{l}\text { Northwestern Mon- } \\
\text { tana. }\end{array}$ & I, 534 & $\begin{array}{l}\text { Rugged mountain region of unsurpassed alpine } \\
\text { character- } 250 \text { glacier-fed lakes of romanti } \\
\text { beauty }-60 \text { small glaciers-Precipices thou- } \\
\text { sands of feet deep-Almost sensationa } 1 \text { scenery } \\
\text { of marked individuality - Fine trout fishing. }\end{array}$ \\
\hline$\underset{\text { Rocky }}{\text { Rountain }}$ & $\begin{array}{l}\text { North Middle Colo- } \\
\text { rado. }\end{array}$ & $397 \frac{1}{2}$ & $\begin{array}{l}\text { Heart of the Rockies-Snowy range, peaks II, } 000 \\
\text { to } 14,250 \text { f eet altitude-Remarkable records of } \\
\text { glacial period. }\end{array}$ \\
\hline $\begin{array}{r}\text { Hawaii...... } \\
\text { I9i6 }\end{array}$ & Hawaii... & II 8 & $\begin{array}{l}\text { Three separate areas-Kilauea and Mauna Loa } \\
\text { on Hawaii; Haleakala on Maui. }\end{array}$ \\
\hline $\begin{array}{c}\text { Lassen Volcanic.... } \\
\text { 1916 }\end{array}$ & Northern California. . & 124 & $\begin{array}{l}\text { Only active volcano in Unit } \\
\text { Lassen Peak, I0,465 f eet- } \\
\text { f eet-Hot springs-Mud gey }\end{array}$ \\
\hline$\underset{\text { I9I } 7}{\operatorname{Mount}} \underset{\mathrm{IcK}}{\operatorname{Minley}}$ & South central Alaska.. & 2,200 & $\begin{array}{l}\text { Highest mountain in North America-Rises } \\
\text { higher above surrounding country than any } \\
\text { other mountain in the world. }\end{array}$ \\
\hline$\underset{\text { IgI9 }}{\underset{\text { Grand Canyon .. }}{4}}$ & North central Arizona. & 958 & $\begin{array}{l}\text { The greatest example of erosion and the most } \\
\text { sublime spectacle in the world. }\end{array}$ \\
\hline $\begin{array}{r}\text { Lafayette.... } \\
\text { I9I9 }\end{array}$ & Maine coast. & 8 & $\begin{array}{l}\text { The group of granite mountains upon Mount } \\
\text { Desert Island. }\end{array}$ \\
\hline Zion......... & Southwestern Utah. & I 20 & $\begin{array}{l}\text { Magnificent gorge ( } Z \text { ion Canyon), depth from } 800 \\
\text { to } 2,000 \text { feet, with precipitous walls-Of great } \\
\text { beauty and scenic interest. }\end{array}$ \\
\hline
\end{tabular}




\title{
TIIE FOSSIL FORESTS OF TILE YELLONSTONE NATIONAL PARK.
}

\author{
By F. H. KNowtion, \\ United States Geological Survey.
}

INTRODUCTION.

Isolated pieces of fossil wood are of comparatively common and widespread cccurrence, especially in the more recent geological deposits of the West. Not infrequently scattered logs, stumps, and roots of petrified or lignitized trees are brought to light, but only exceptionally are they so massed and aggregated as to be worthy of the designation of fossil forests. Examples of such are the celebrated fossil forests of relatively late geological age near Cairo, Egypt, the huge prostrate trunks in the Napa Valley near Calistoga, Cal., and the geologically much older and far more extensive forests now widely known as the Petrified Forest National Monument in Apache County, Ariz. But in many respects the most remarkable fossil forests known are those now to be described in the Tellowstone National Park. In the forests first mentioned the trunks and logs were all prostrated before fossilization, and it is perhaps not quite correct to designate such aggregations as veritable fossil forests, though they usually are so called. In the fossil forests of Arizona, for example, which are scattered over many square miles of what is now almost desert, all the trunks show evidence of having been transported from a distance before they were turned to stone. Most of them are not even in the position in which they were originally entombed, but have been eroded from slightly higher horizons and have rolled in the greatest profusion to lower levels. Is one views these Arizona forests from a little distance, with their hundreds, even thousands, of segments of logs, it is difficult to realize that they are really turned to stone and are now exhumed from the earth. The appearance they present (see fig. 1) is not unlike a "log drive" that has been stranded by the receding waters and left until the bark had disappeared and many logs had fallen into partial decay. Trunks of many sizes and lengths are now mingled and scattered about in the wildest profusion, and the surface of the ground is carpeted with fragments of wood that have been splintered and broken from them. In the Yellowstone National Park, however, most of 
the trees were entombed in the upright position in which they grew, by the outpouring of various volcanic materials, and as the softer rock surrounding them is gradually worn away they are left standing erect on the steep hillsides, just as they stood when they were living; in fact, it is difficult at a little distance to distinguish some of these

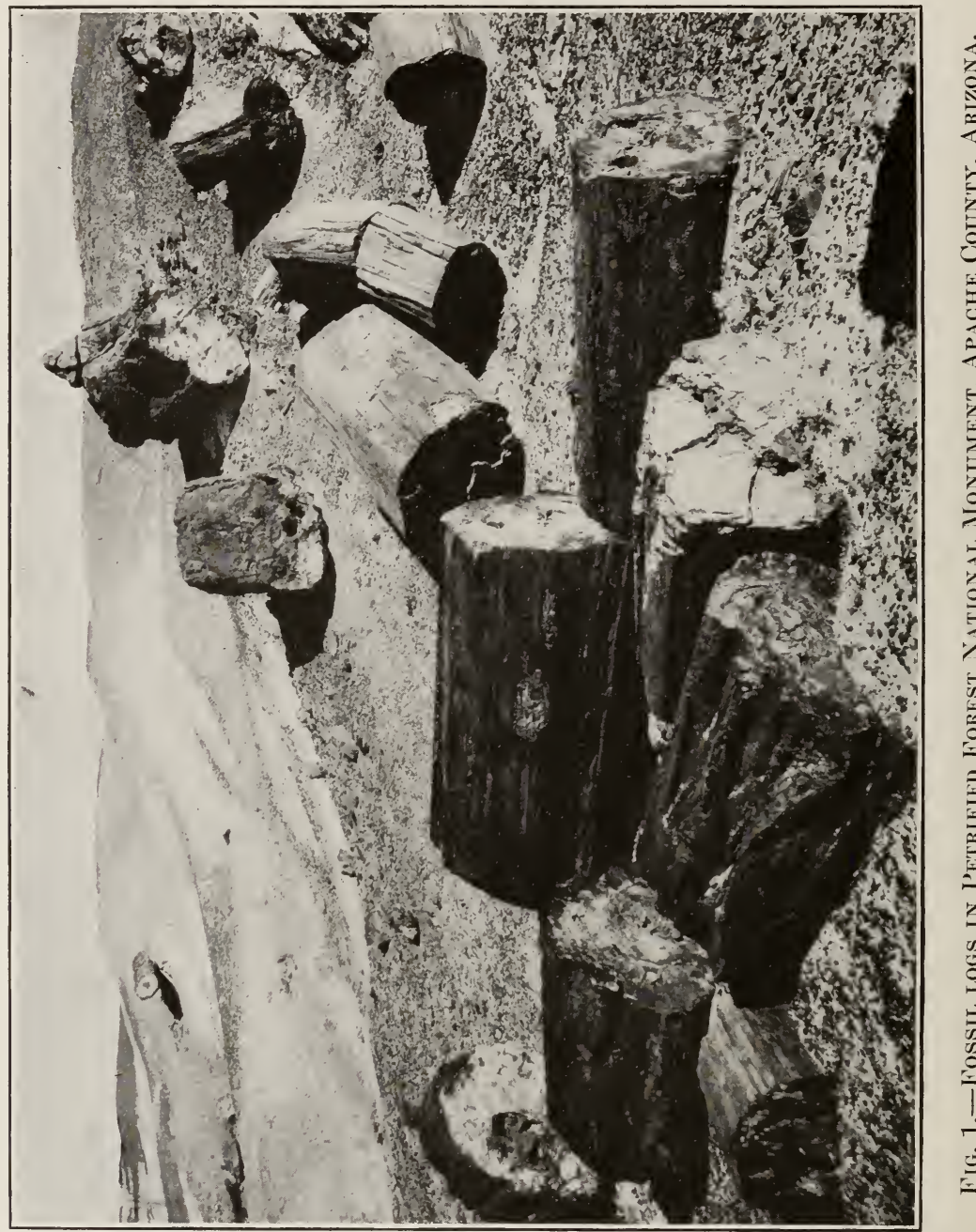

fossil trunks from the lichen-covered stumps of kindred living species. Such an aggregation of fossil trunks is therefore well entitled to be called a true fossil forest. It should not be supposed, however, that these trees still retain their limbs and smaller branches, for the mass of volcanic material falling on them stripped them down to bare, upright trunks. 
The fossil forests of the Tellowstone National Park cover an extensive area in the northern portion of the park, being especially abundant along the west side of Lamar River for about 20 miles above its junction with the Yellowstone. Here the land rises rather

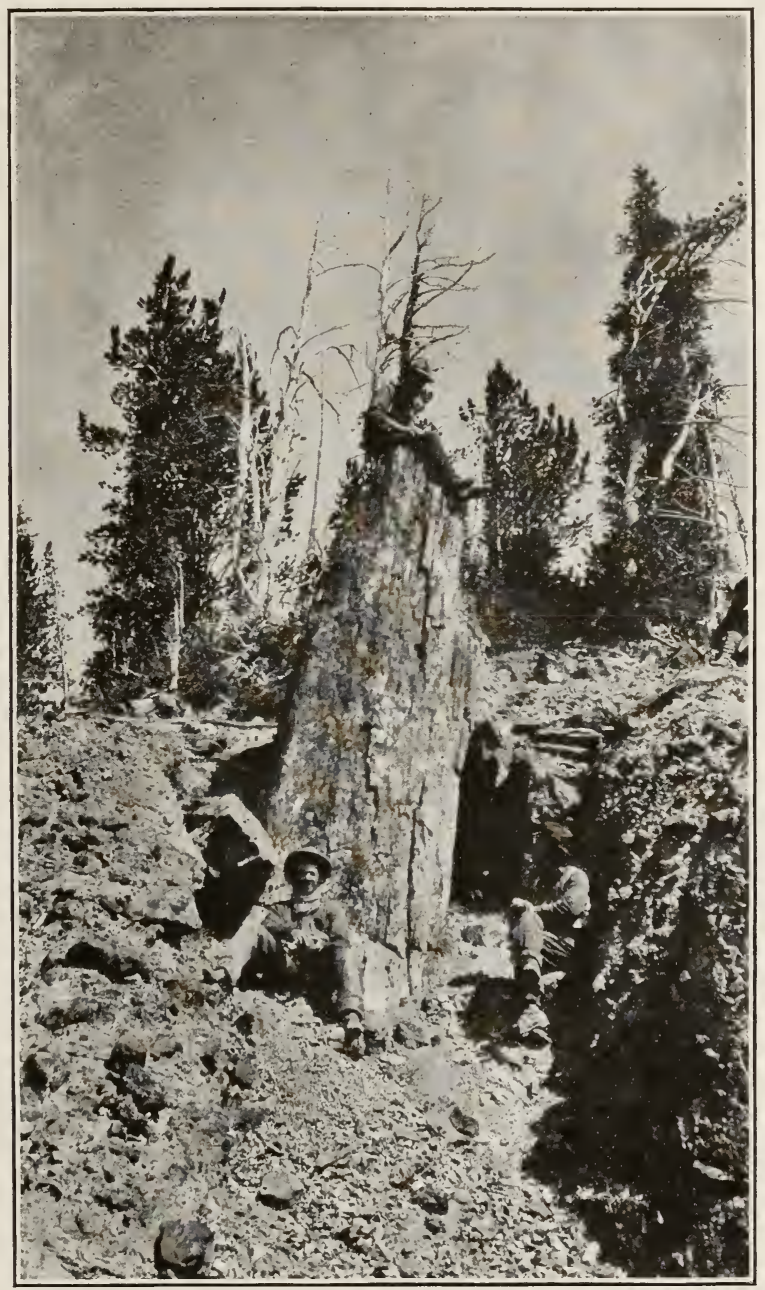

Fig, 2.-Upright fossil trunk in Gallatin Mountains, Montana.

Courtesy of E. C. Alderson.

abruptly to a height of approximately 2,000 feet above the valley floor. It is known locally as Specimen Ridge, and forms an approach to Amethyst Mountain. There is also a small fossil forest containing a number of standing trunks near Tower Falls, and near the eastern border of the park along Lamar River in the vicinity of Cache, Calfee, and Miller Creeks, there are many more or 
less isolated trunks and stumps of fossil trees, but so far as known none of these are equal in interest to the fossil forest on the slopes of Specimen Ridge.

The fossil forests are reached over a road from the Mammoth Hot Springs, or from Camp Roosevelt near Tower Falls, and they are

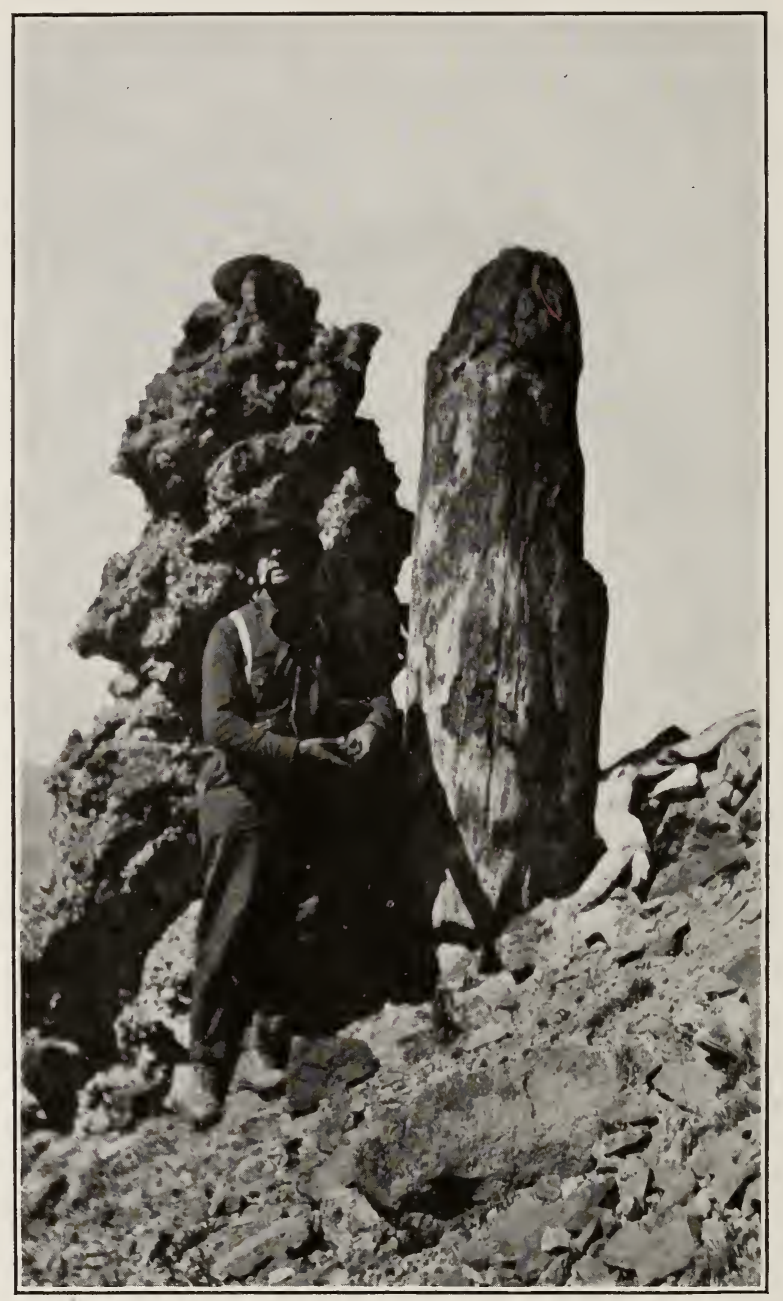

Fig. 3.-UpRight trink and " hoodoo" in Gallatin Mountains, Montana.

Courtesy of E. C. Alderson.

in their way quite as wonderful and worthy of attention as many of the other features for which the Yellowstone National Park is so justly celebrated.

Recently another extensive fossil forest has been found on the divide between the Gallatin and Yellowstone Rivers in the Gallatin 
Range of mountains, in Park and Gallatin Counties, Mont. This forest, which lies just outside the boundary of the Yellowstone National Park, is said to cover 35,000 acres and to contain some wonderfully well preserved upright trunks, many of them very large, equaling or perhaps even surpassing in size some of those within the limits of the park. Two of the best preserved of these trunks are shown in figures 2 and 3, which are here reproduced by the kindness of Mr. E. C. Alderson, of Bozeman, Mont.

In the beds of the streams and gulches coming down into the Lamar River from Specimen Ridge and the fossil forests one may observe numerous pieces of fossil wood, which may be traced for a long distance down the Lamar and Yellowstone Rivers. The farther these pieces of wood have been transported downstream, the more they have been worn and rounded, until ultimately they become smooth, rounded "pebbles" of the stream bed. The pieces of wood become more numerous and fresher in appearance upstream toward the bluffs, until at the foot of the cliffs in some places there are hundreds, perhaps thousands of tons that have but recently fallen from the walls above. One traversing the valley of the Lamar River may see at many places numerous upright fossil trunks in the faces of nearly vertical walls. These trunks are not all at a particular level but occur at irregular heights; in fact a section cut down through these 2,000 feet of beds would disclose a succession of fossil forests (see fig. 4). That is to say, after the first forest grew and was entombed, there was a time without volcanic outburst-a period long enough to permit a second forest to grow above the first. This in turn was covered by volcanic material and preserved, to be followed again by a period of quiet, and these more or less regular alternations of rolcanism and forest growth continued throughout the time the berls were in process of formation.

\section{GEOLOGIC RELATIONS.}

While these fossil forests were growing and being entombed, much of the area now within the limits of the park, as well as large adjacent areas, was the scene of tremendous geologic activities. After the Cretaceous period (see diagram p. 30), there was a time of great volcanic activity, which appears to have lasted until perhaps the beginning of the glacial epoch. There were many active volcanoes just east, north, and west of the park, and some in the park itself. From these volcanoes vast quantities of material were poured out, building up in places whole mountain ranges. Thus the major portion of the great Mbsaroka Range, just east of the park, as it appears to-day, was built up of volcanic material. 


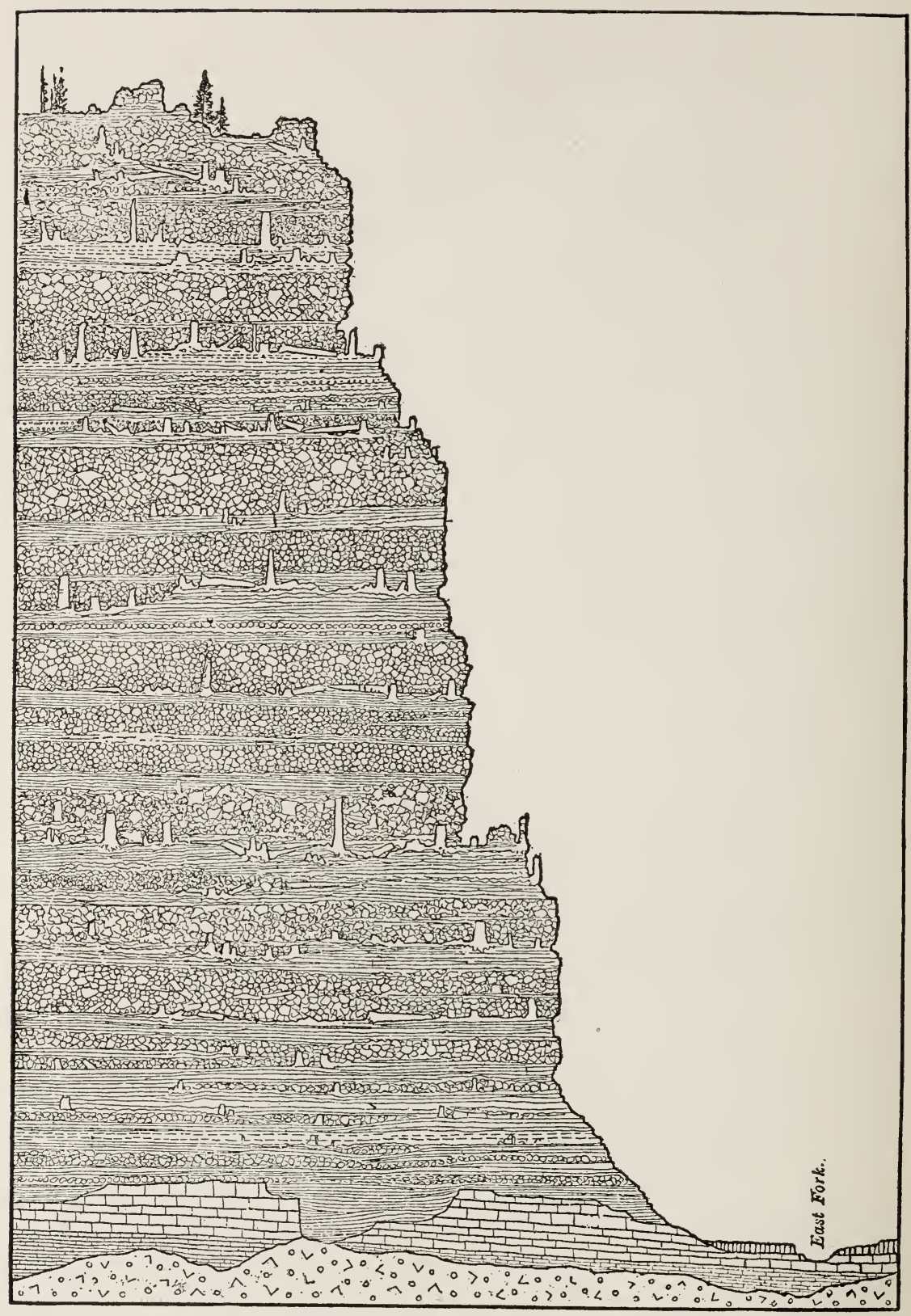

Fig. 4.-Ideal section thinough 2,000 feet of beds of Specinen Iiddge, showing SUCCESSION OF BURIFD FOREst. AFTER HoLMES. 
Mr. Arnold Hague gives the following graphic account of this and adjacent areas:

From one end to the other the Absarokis present a high, imposing plateau, witl elevations ranging from 10,000 to over 12,000 feet above seal level. The entire mass is made up almost exchusively of. Tertiary igneous rocks. * * * Degradation of the mass has taken place on a grand scale. Vast quantities of volcanic ejectmenta have been removed from the summit, but no reliable data exist by which the amount can be estimated even approximately. All the higher portions have been sculptured by glacial ice. Enormous amphitheaters have been carved out of the loose agglomerates, and peaks, pinnacles, and relics of great table-lands testify in some measure to the forces of erosion. The plateau is scored by a complete network of deep valleys and gorges, which dissect it in every direction, and lay bare the structure of the vast volcanic pile. ${ }^{1}$

Within the park there is evidence of similar volcanic activity, and it is clear that the basin between the encircling ranges was filled to its present elevation by volcanic flows, which formed the present park plateau. The area within which the fossil forests are now found was apparently in the beginning an irregular but relatively flat basin, on the floor of which after a time there grew the first forest. Then there came from some of the volcanoes, probably those to the north, an outpouring of ashes, mud flows, and other material which entirely buried the forest, but so gradually that the trees were simply submerged by the incoming material, few of them being prostrated. On the raised floor of the basin, after a time, the next forest came into existence, only to be in turn engulfed as the first had been, and so on through the period represented by the 2,000 feet or more of similar beds. The series of entombed forests affords a means of making at least a rough estimate of the time required for the upbuilding of what is now Specimen Ridge and its extensions. (See p. 29.)

During the time this 2,000 feet of material was being accumulated, and since then to the present day, there has been relatively little warping of the earth's crust at this point; that is, the beds were then, and still are, practically horizontal, so that the fossil forests, as they are being gradually uncovered, still stand upright.

When the rolcanic activities had finally ceased, the ever-working disintegrating forces of nature began to tear and wear down this accumulated material, eroding the beds on a grand scale. Deep canyons and gulches have been trenched, and vast quantities of the softer materials have been carried away by the streams and again deposited on lower levels or transported to great and unknown distances.

As the material in which the fossil forests are now entombed consist of ashes, mud flows, breccia, and the like not all the beds are of the same texture and hardness, so that erosion has acted unerenly on

${ }^{1}$ Hague, Arnold, Early Tertiary Volcanoes of the Absaroka Range: Geol. Soc. Wash., Presidential Address, 1899 , p. 4.

$36090^{\circ}-21-2$ 
them and has produced many peculiar rock forms. 'The grotesque so-called "hoodoos" have been carved out in this manner. The fossil trunks, being usually harder than the surrounding matrix in which they are embedded, have more firmly resisted erosion and now project to different heights above the general level. In exposed beds that are nearly or quite horizontal, disintegration has acted at nearly equal pace on the trunks and on the matrix, so that the trunks are nearly or quite on a level with the surrounding surface. On steep hillsides, however, from which all loose material is easily and quickly removed, some of the fossil trunks stand up to a height of 20 or 30 feet. If the beds had been tilted at a considerable angle, these trunks could project from the surface for only a short distance before their weight would break them off, showing again the remarkably stable conditions that have continued since the trunks were covered up.

\section{AMETHYST MOUNTAIN.}

The fossil forest that was first brought to scientific attention is on the northern slope of Amethyst Mountain. opposite the mouth of Soda Butte Creek, 12 miles southeast of Camp Roosevelt. The following account, by Dr. William H. Holmes, the discoverer of these fossil forests, shows the impression first made by them:

As we ride up the trail that meanders the smooth river bottom [Lamar River] we have but to turn our attention to the cliffs on the right hand to discover a multitude of the bleached trunks of the ancient forests. In the steeper middle portion of the mountain face, rows of upright trunks stand out on the ledges like the columns of a ruined temple. On the more gentle slopes farther down, but where it is still too steep to support regetation, save a few pines, the petrifie: trunks fairly cover the surface, and were at first supposed by us to be shattered remains of a recent forest. ${ }^{1}$

These trunks may easily be seen from the road along the Lamar River, about a mile away. They stand upright-as Iolmes has said, like the pillars of some ruined temple-and a closer view shows that there is a succession of these forests, one above another. In the foothills and several hundred feet above the valley there is a perpendicular wall of rolcanic breccia, which in some places attains a height of nearly 100 feet. The fossil trunks may be seen in this wall in many places, all of them standing upright, in the position in which they grew. Some of these trunks, which are 2 to 4 feet in diameter and 20 to 40 feet high, are so far weathered out of the rock as to appear just ready to fall; others are only slightly exposed; niches mark the places from which others have already fallen; and the foot of the cliff is piled high with fragments of various sizes.

1 Holmes, W. II., Twelfth Ann. Rept. U. S. Geol. and Geogr. Surv. Terr., 1878 (1883), p. 48 . 
Above this cliff fossil trunks appear in great number's and in regular succession. As they are all perfectly silicified, they are more resistant than the surrounding matrix and consequently stand above it. Most of them are only a few inches above the surface, but occasionally one rises as high as 5 or 6 feet. The largest trunk observed in the park is found in this locality. It is a little over 10 feet in diameter, a measurement that includes a part of the bark. It is rery much broken down, especially in the interior, probably having been so disintegrated before it was fossilized. It projects about 6 feet above the surface.

At many places about Amethyst Mountain there are numerous fragments of fossil wood and many hollow trunks. The material in which they had been embedded has been eroded away, and they lie around in somewhat the same attitudes that are shown by all the trunks in the Arizona fossil forests, but there is little doubt that they were originally erect and have simply fallen by their own weight because of the removal of the material around them.

Many of the trunks here, as well as elsewhere in the park, had decayed in the center before they were fossilized, and some of the hollow interiors are filled with clusters and rosettes of beautiful crystals of amethyst, which doubtless suggested the name given to the adjacent mountain. Much of this finely preserved wood, as well as the trunks containing the crystals of amethyst, was broken up and carried away by collectors of minerals and curiosities before the Government control in the park was made sufficiently rigid to insure proper protection.

\section{SPECIMEN RIDGE.}

In many respects the most remarkable of the fossil forests is on the northwest end of Specimen Ridge, about a mile southeast of Junction Butte and about opposite the mouth of Slough Creek. So far as known, this forest was first brought to scientific attention by Mr. E. C. Alderson, of Bozeman, Mont., and the writer, who discovered it in August, 1887. It is found on the higher part of the ridge, and covers several acres. The trees are exposed at various heights on the very steep hillsides, and one remarkable feature of the forest is that most of them project well above the surface.

One of the largest and best preserved trees stands at the very summit of the slope (see title page). This trunk, which is that of a giant redwood, is $26 \frac{1}{2}$ feet in circumference without the bark and about 12 feet in height. The portion of this huge trunk preserved is the base, and it exhibits to a considerable degree the swelling or buttressing so well known in the living redwood. The roots, which are as large as the trunks of ordinary trees, are now embedded in solid rock. 
On the steep hillside a short distance below the big tree just mentioned are the two trunks shown in figure 5. They are about 2 feet

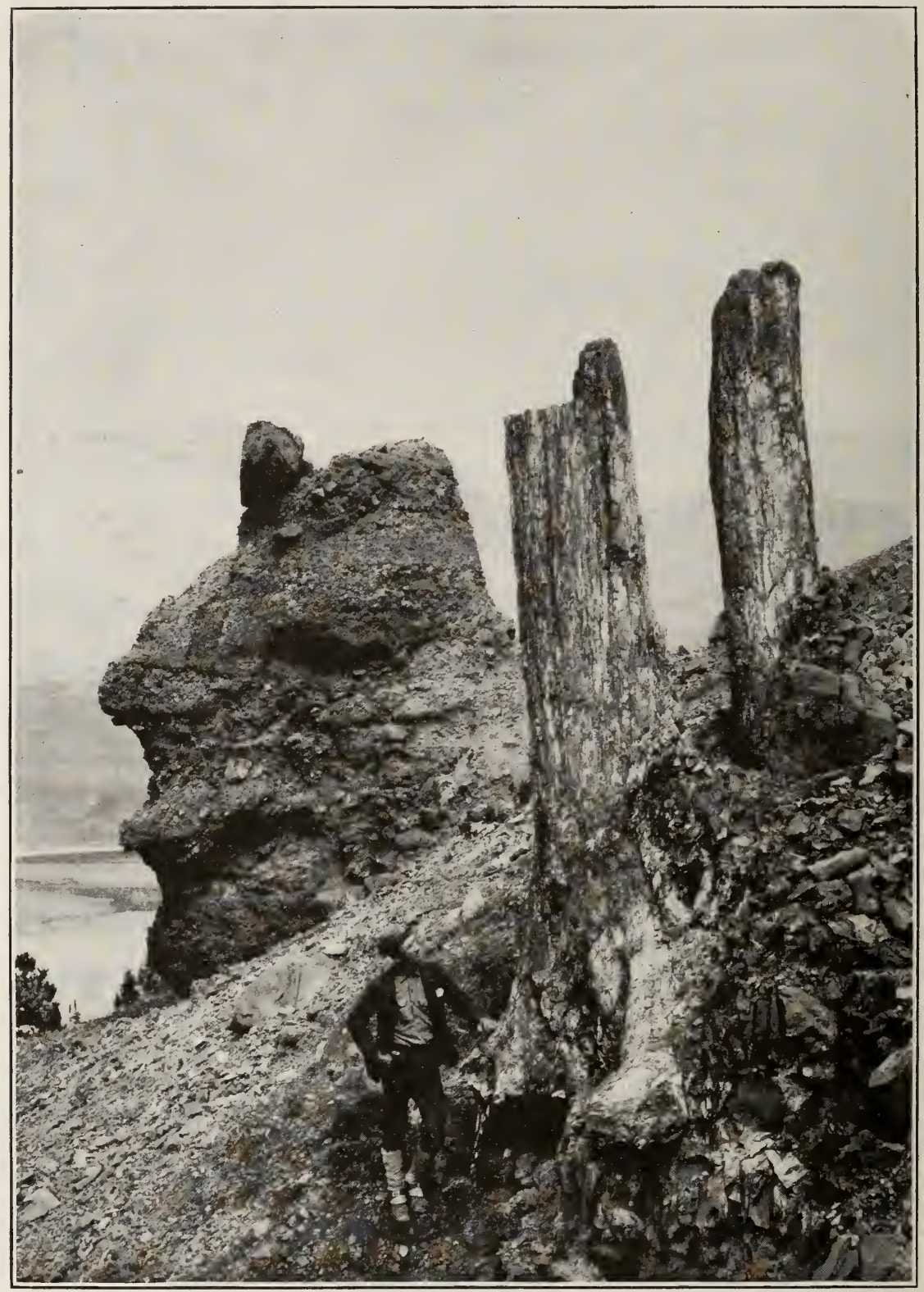

Fig. 5.-Upright trunks in Specimen Ridge fossil forest.

in diameter and 25 feet high, and stand some 20 feet apart, and we may imagine them to have formed the doorposts of the "ancient 
temple" of which Holmes speaks. Both these trunks are without the bark. On the left of the figure is one of the huge irregular masses of rock that has been carved out by erosion.

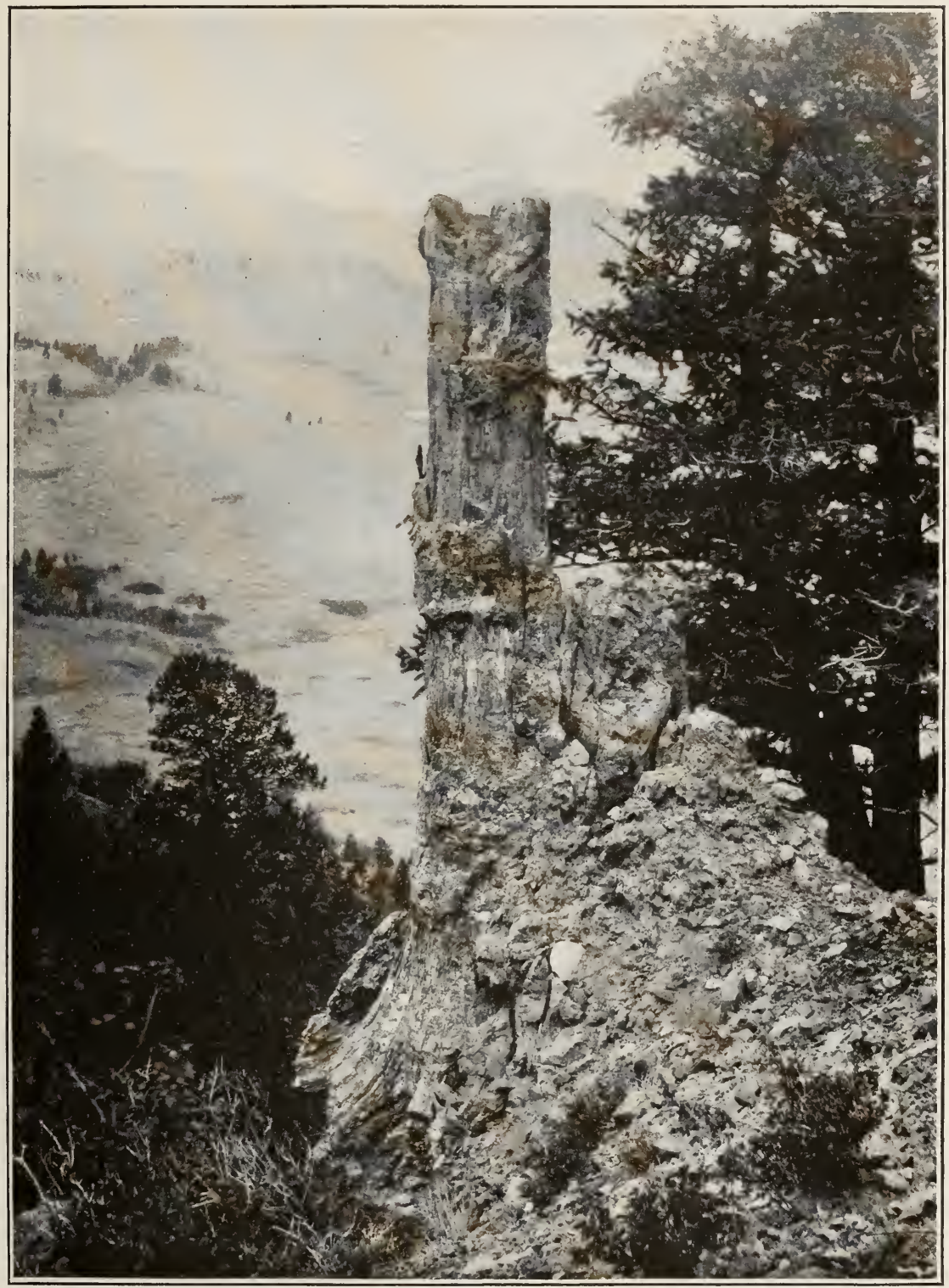

Fig. 6.-Trunk of fossil pine silowing bark, Specinen Ridge fossil forest.

In figure 6 is shown another trunk about 3 feet in diameter and nearly 30 feet high. In several places along the trunk the thick bark may be noted. This tree is a pine, as are the two last described, and 
slightly below and behind it are two living pine trees, which are about the size it must have been when living. Another trunk, some 12 feet in height, is shown in figure 7 , and in figure 8 there may be noted a standing trunk and above it another that has recently fallen.

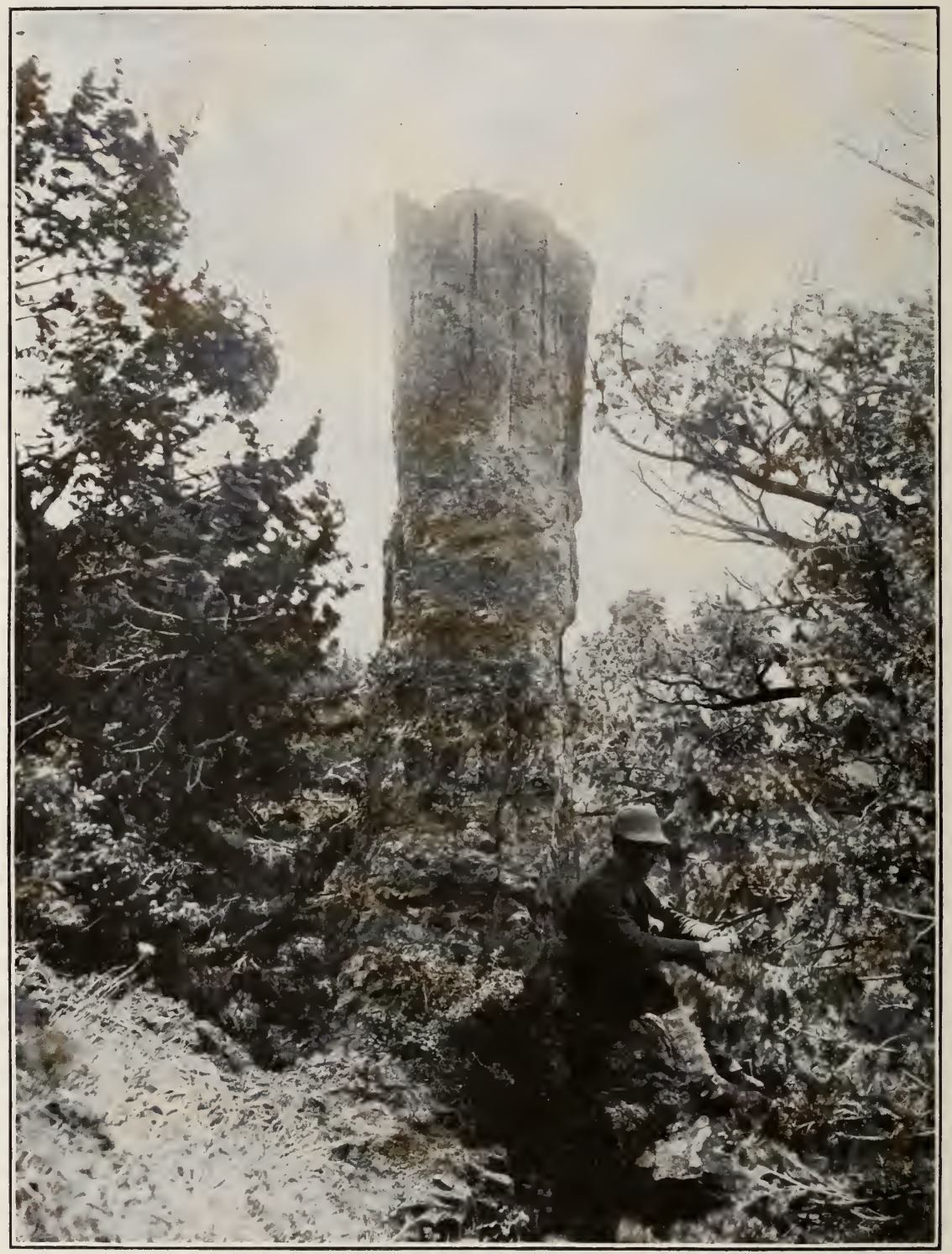

Hig. 7.-Trunk showing BARK, SPECIMEN Ridge Fossil Forest.

The height attained by the trees of this fossil forest can not be ascertained with certainty, since the tallest trunk now standing is only about 30 feet high, but every one observed is obviously broken 
off, and does not show even the presence of limbs. Perhaps the nearest approach to a measure of the height is afforded by a trunk (shown in fig. 10) that happened to have been prostrated before fossilization. This trunk, which is 4 feet in diameter, is exposed for a length of about 40 feet, and as it shows no apparent diminution in size

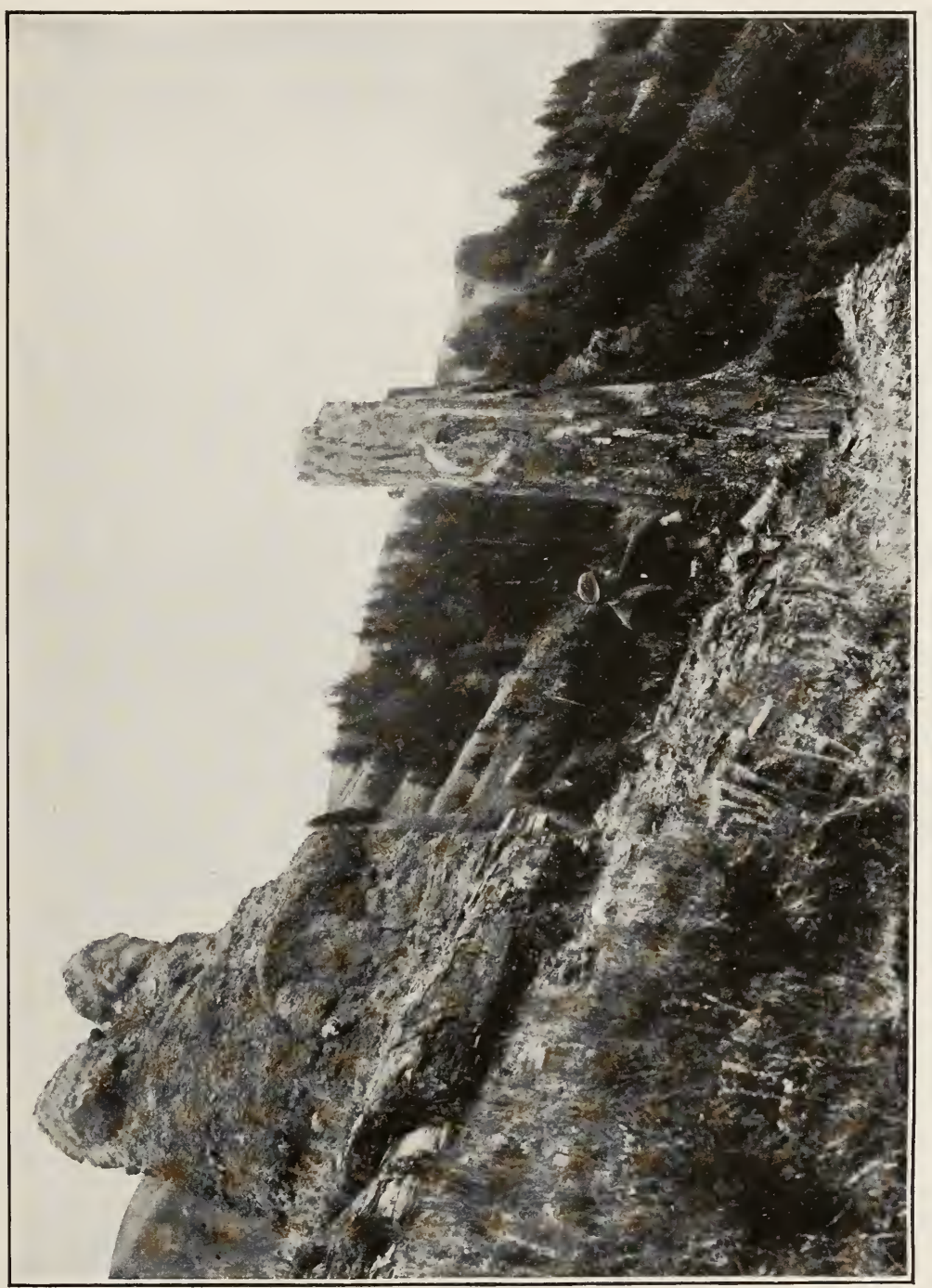

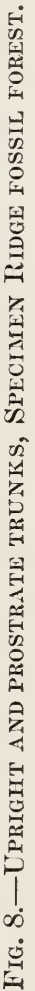

within this distance it is safe to assume that the tree could hardly have been less than 100 feet high and very probably may have been higher. This trunk is wonderfully preserved. As may be seen from the illustration, it has broken up by splitting along the grain of the wood into great numbers of little pieces, which closely resemble 
pieces of "kindling wood" split from a clear-grained block. In fact, at a distance of a few yards it would be impossible to distinguish this fossil " kindling wood" from that split from a living tree.

The large redwood trunk already mentioned (title-page) as being nearly 10 feet in diameter may be compared with its living relative

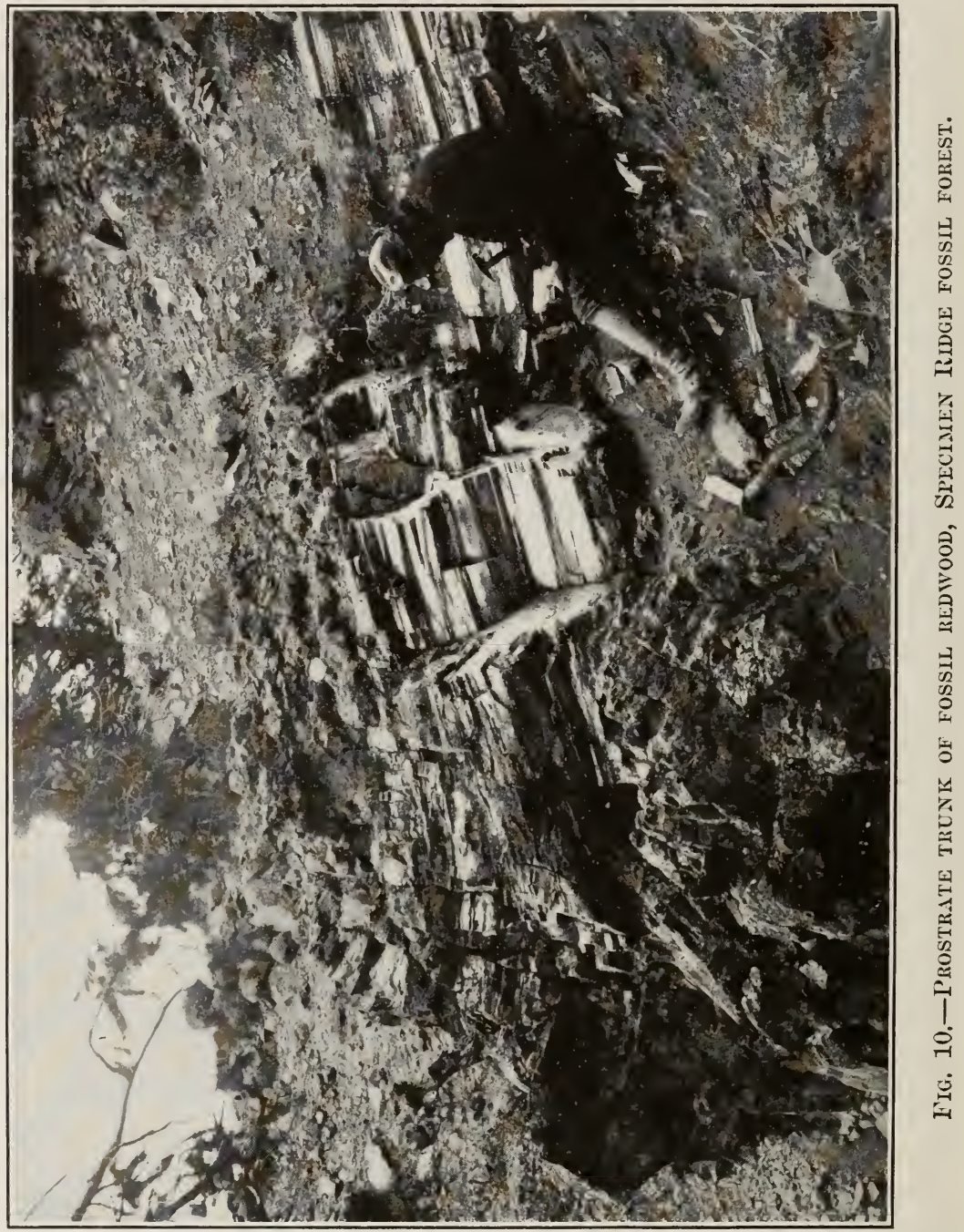

of the Pacific coast in order to calculate its probable height. The living redwood is usually 10 to 15 feet in diameter and ranges in height from 200 to 340 feet, and as the two are so rery closely related there is no reason to suppose that the fossil trunk was of less height, but by a moderate estimate it may be accredited with a minimum height of 200 feet. 



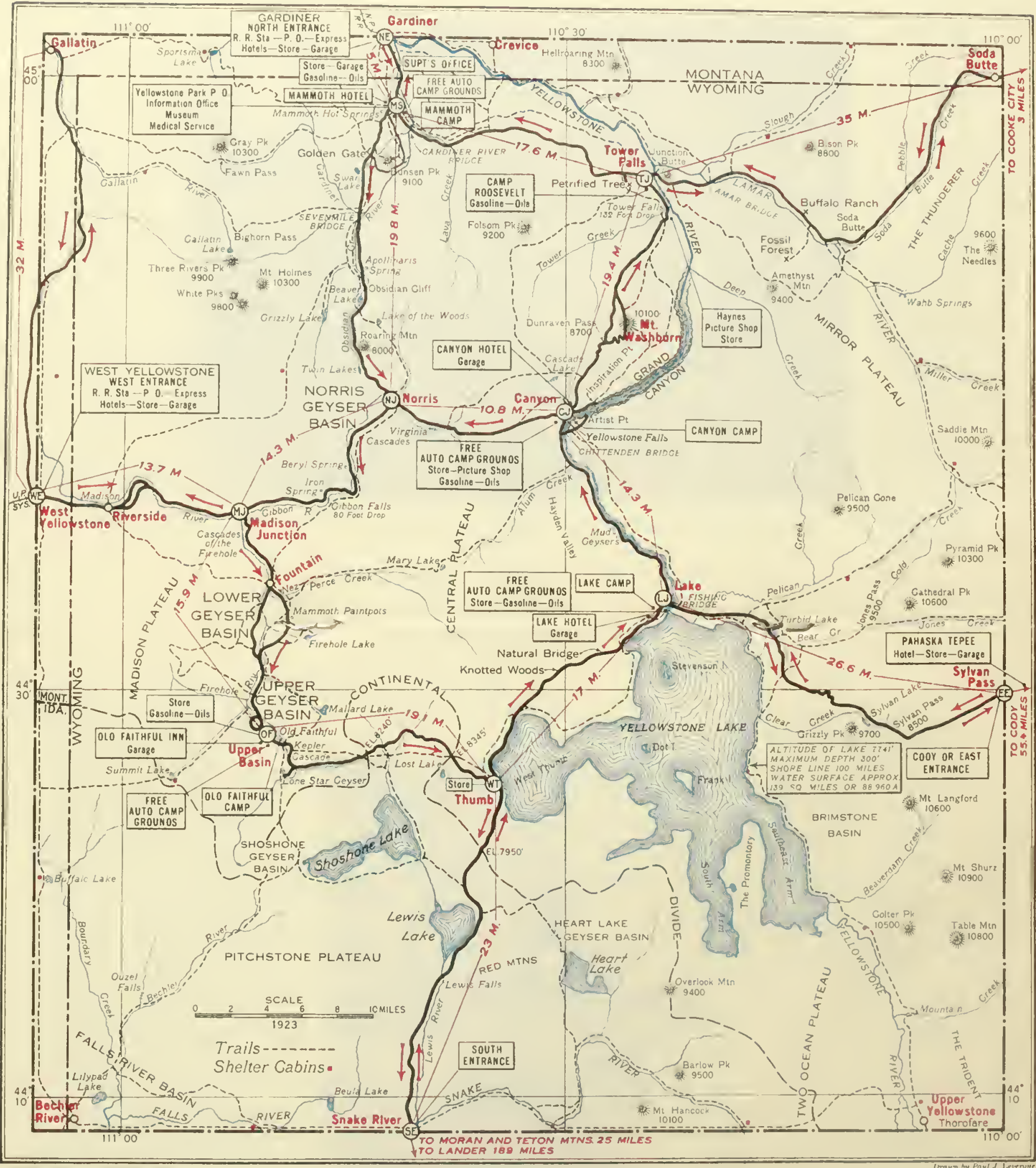

MAP OF YELLOWSTONE NATIONAL PARK Morris ODenotes Ranger Station $\longleftarrow$ Direction of Travel

Distances given are between main points by road

NOTE THE MILE-POST SIGNS 


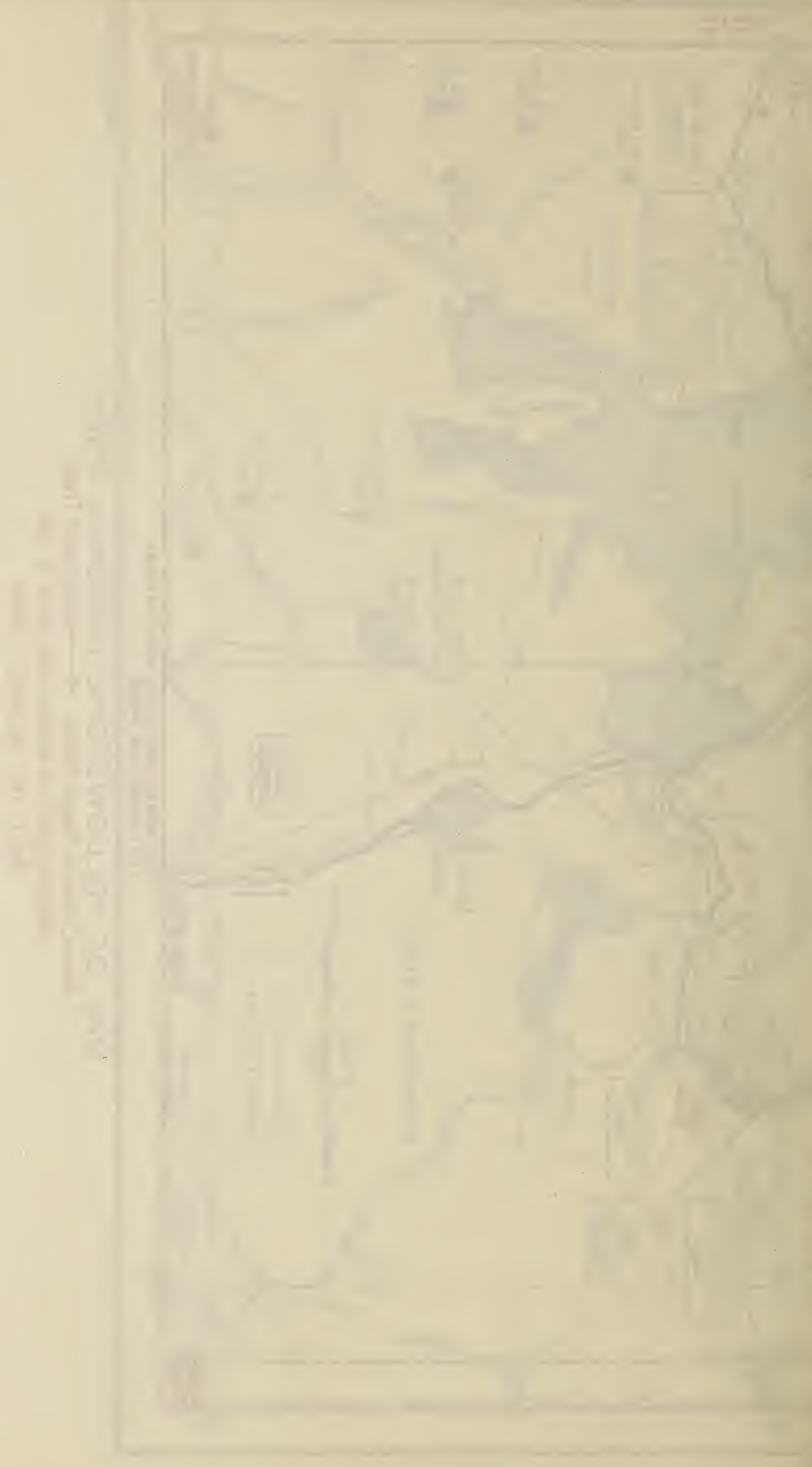


TOWER FALLS.

The most accessible fossil forest. marked "Petrified Trees" on the map is west of the Tower Falls Ranger Station and Camp Roosevelt on the road from the Grand Canyon to Mammoth Hot Springs, by way of Mount Washburn. It is on the middle slope of a hill that rises about 1,000 feet above the little valley and may be reached by a branch road from the main loop road. As the traveler approaches the forest he will observe a number of trunks standing upright among the stumps and trunks of living trees, and so much

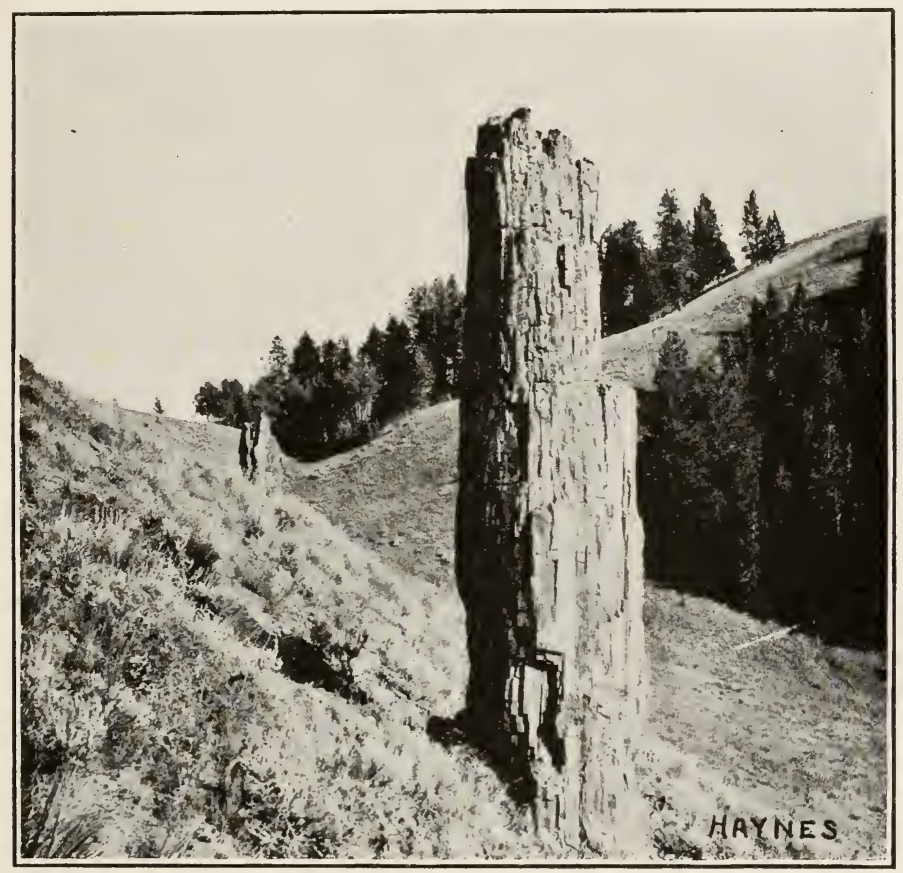

Fig. 11.-Fossil trunk near Tower falles.

Photograph by F. J. Haynes.

resembling them that a near view is necessary to convince him that they are really fossil trunks. Only two rise to a considerable height above the surface. The larger one is about 15 feet high and 13 feet in circumference (fig. 11); the other is a little smaller. As the roots are not exposed, it is impossible to determine the position of the part in view or the original diameter of the trees, as the bark is nowhere preserved.

Above these standing trunks lie many others, which the disintegrating forces of nature break up into small fragments and keep at about the same level as that of their surrounding matrix. Some of these trunks rise only a few inches from the surface; others are 
nearly covered by shifting débris. Their diameter ranges from 1 to 4 feet, and they are so perfectly preserved that the rings of growth can easily be counted. The internal structure is also in most trunks nearly as perfect as when the trees were living.

\section{CACHE CREEK.}

The forest that is next in size to the one a mile southeast of Junction Butte is on Cache Creek, about 7 miles above its mouth. It is on the sonth bank of the creek and covers several acres. The trunks are scattered from bottom to top of the slopes through a height of probably 800 feet. Most of the trunks are upright, but only a few project more than 2 or 3 feet above the surface. The largest one observed was 6 feet in height and 4 feet in diameter. Most of these trunks appear to the naked eye to be conifers, but a number are obviously dicotyledons-that is, they were deciduous-leared trees. The conifers, however, were the predominant element in this as in the other fossil forests.

The slopes of the Thunderer, the mountain so prominently in view from Soda Butte on the south, also bear numerous fossil trunks. Most of them are upright, but only a very few project more than 2 feet above the surface. No remarkably large trunks were observed at this locality, the average diameter being perhaps less than 2 feet.

\section{OTHER LOCALITIES.}

Mount Norris, which is hardly to be separated from the Thunderer, also bears a small fossil forest. The trees are of about the same size and character as those in the larger mountain. Fossil forests of greater or less extent, composed mainly of upright trunks, are exposed also on Baronett Peak, Bison Peak, Abiathar Peak, Crescent Hill, and Miller Creek. In fact, there is hardly a square mile of the area of the northeastern portion of the park that is without its fossil forest, scattered trunks, or erratic fragments.

The vast area east of the Yellowstone Lake and the region still farther east, beyond the limits of the park, have not been thoroughly explored, but enough is known to make it certain that these areas contain more or less fossil wood. The stream beds in these areas in many places contain fragments of fossil wood, which indicates that trunks of trees must be near at hand.

\section{THE PROCESS OF FOSSILIZATION.}

The manner in which these forests were fossilized may next be considered. Though the whole history of the process is not fully understood, it was undoubtedly dependent on or at least greatly facilitated by the presence of volcanic and hydrothermal activity, 
which was doubtless then, as it is to some extent now, a marked feature of the park region. At least a hint of the probable process is afforded by the action now going on in the hot spring areas. Many of those areas are closely surrounded by forests, and unless the action of the springs is very violent the trees may be growing only a short distance away. Occasionally a hot spring may break out near the edge of a forest, the first effect being, of course, to kill the trees. In a few years, by the action of the ordinary processes of decay, a tree so killed may have lost its bark and most of its smaller branches. The hot water which constantly or intermittently surrounds the tree contains a considerable amount of silica in solution, and as this hot silica-charged water is drawn up into the wood by capillarity the silica may be deposited in the cells of the wood after the water cools or evaporates. The first result will be a more or less complete cast of the interior of the cells and vessels of the wood. This much of the process has actually been observed, but as decay is more rapid than silicification, the wood crumbles to dust before petrifaction is complete. If the trunk could be surrounded by ashes or mud and thus protected from atmospheric action, it might in time be completely turned to stone.

The fossil forests are surrounded by a matrix that is known as an acidic lava-that is, a siliceous lava-which contains abundant silica in solution. The first part of the process of silicification may well have been that above describer as taking place in the hot spring areas at the present day-that is, the silica would be deposited in all the cells and ressels of the wood, making an accurate cast of all open spaces. Then, while the slow process of decay went on, as each particle of organic matter was removed its place was taken by the silica, until, finally, all the wood substance had disappeared and its place atom by atom had been taken by silica.

By this or a similar process the wood has been preserved or fossilized with remarkable fidelity; in fact, thin sections or slices of the fossil wood may be studied under the higher powers of the microscope with almost or quite as much completeness and satisfaction as if they were sections cut from a piece of living wood. Each cell and ressel, with its characteristic pits and markings, is preserved exactly as it grew. Some of the wood, however, was evidently more or less decayed before it was fossilized, or else decay worked faster than replacement, so that in some fragments the structure is not so clearly preserved. Many of the trunks were subjected to pressure before replacement was complete, and this has crushed or distorted the cells. On the whole, however, the wood is exceptionally well preserved, as may be seen in figures 12, 13, 14, and 15. These are all magnified 100 diameters and were photographed directly from the thin sec- 


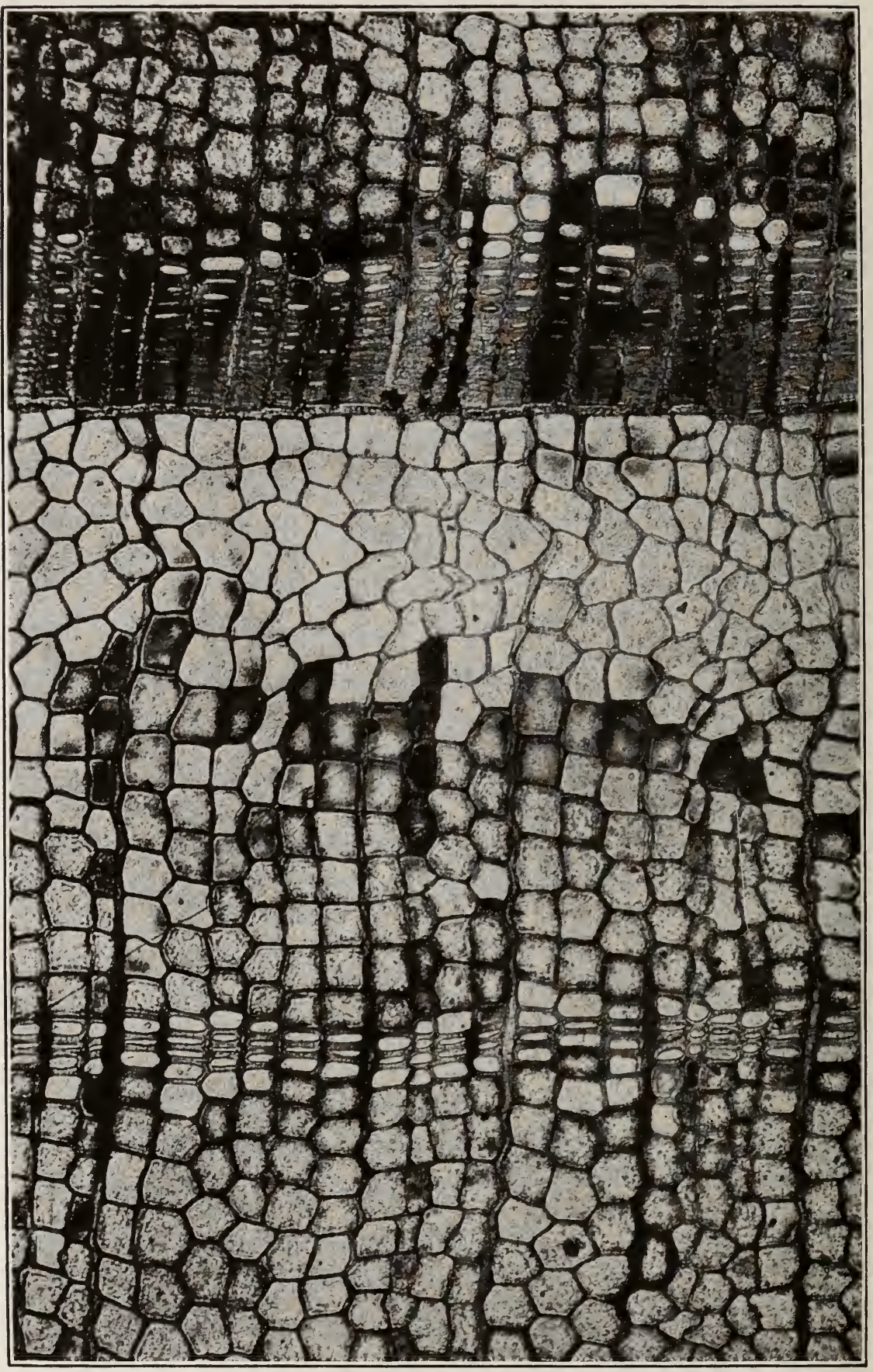

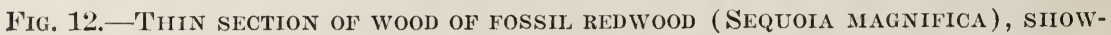
ing GRoWth RiNG. SECtion transverse. MAGNified 100 diameters. 


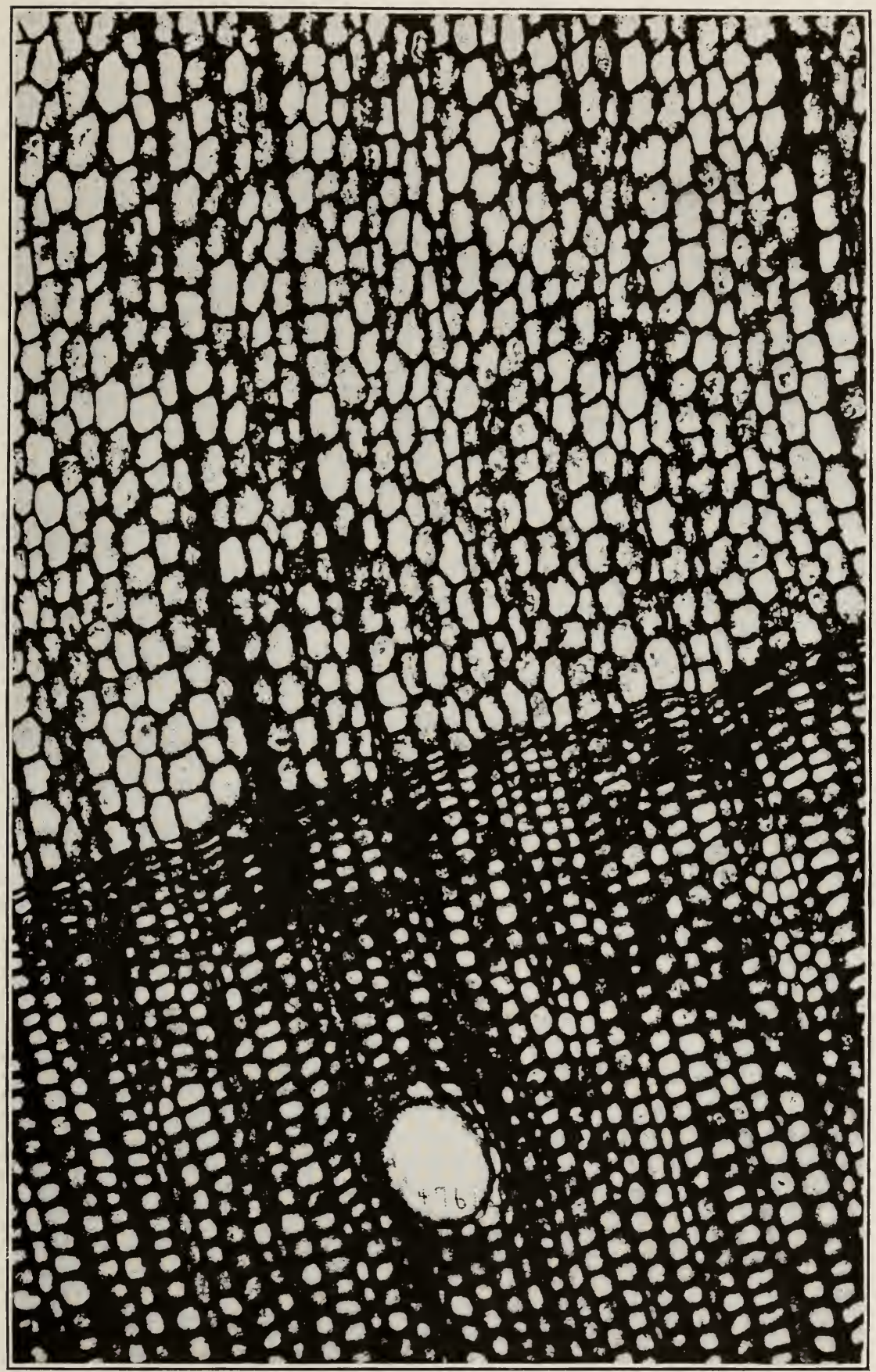

Fig. 13.-Thin section of wood of Fossil PINe (Pityoxylon amethystinum), SHOWING GROWTH RING AND RESIN TUBE. SECTION tranverse. MagNified 100 DIAMETERS. 


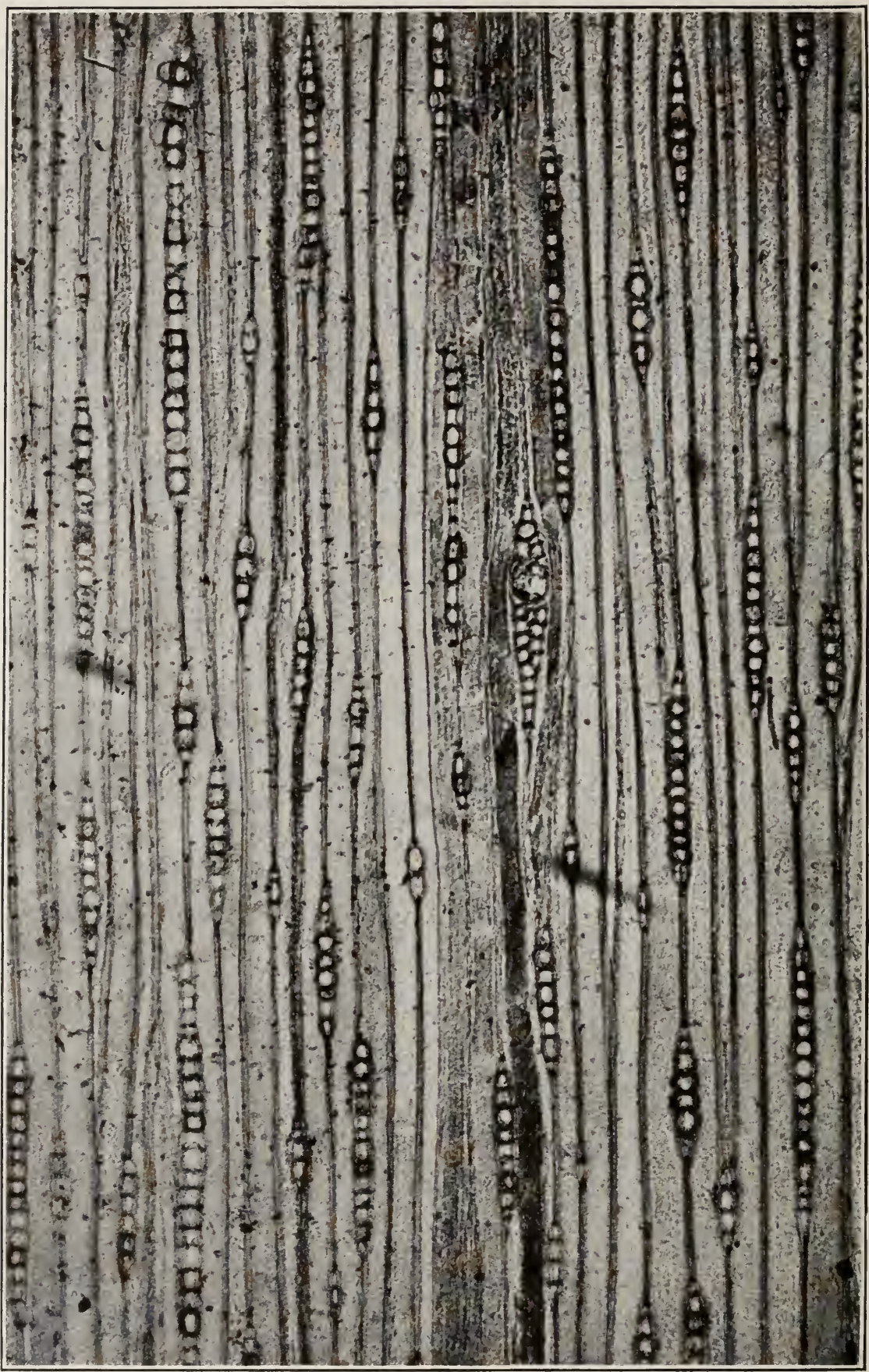

Fig. 14.-Thin Section of wood of Fossil pine (Pityoxylon aldersoni), showiNg Medullary RaYs and Resin tube. SEction tangential. Magnified 100 DIAMETERS. 


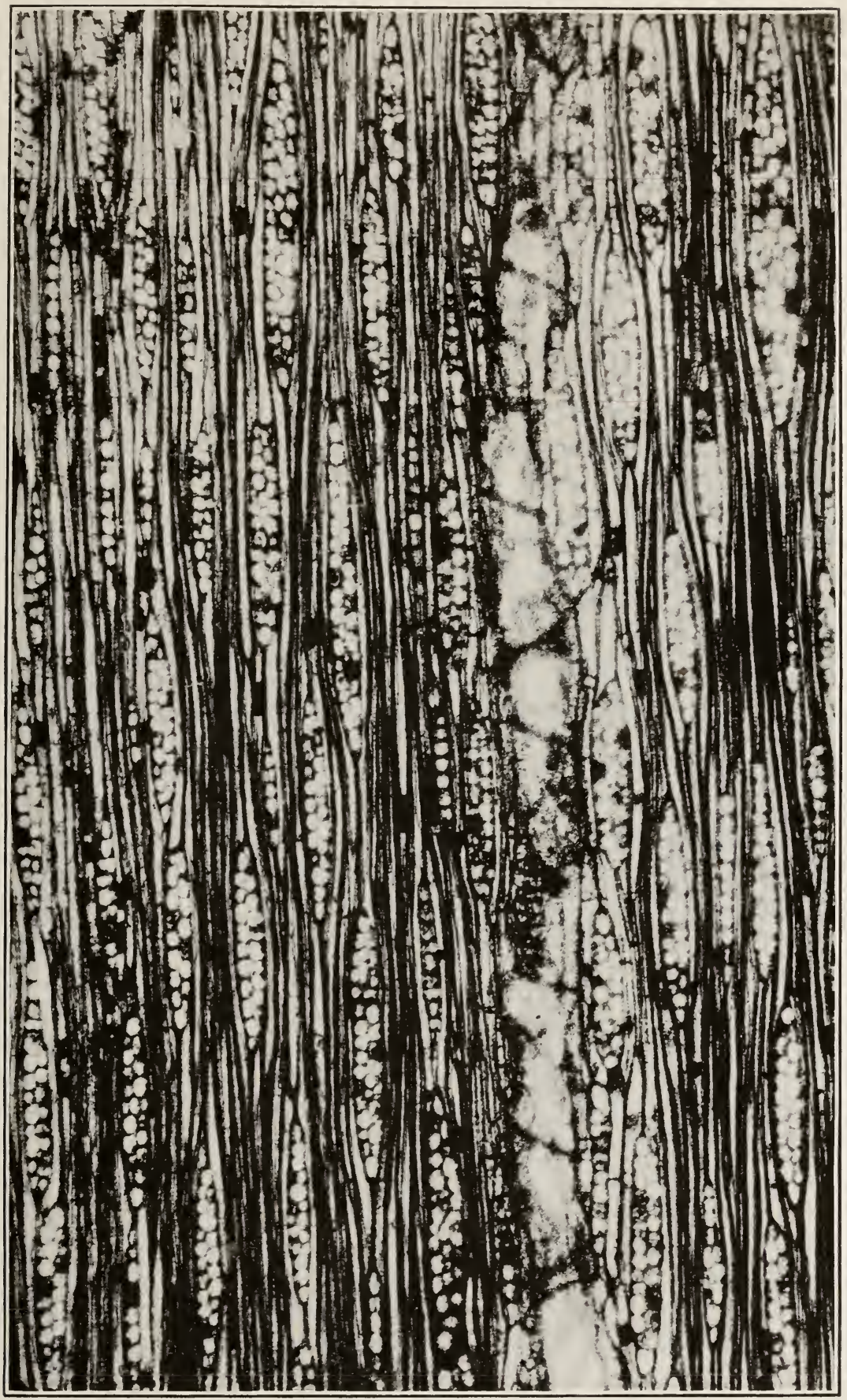

Fig. 15.-TIIIN SECTION OF WOOD OF FOSSIL LAUREL (LAURINOXYLON PULCHRUM), SHOWING WOOD CELls, TUBES, AND RAYS. SECTION LONGITUdINAL. MAGNIFIED 100 DIAMETERS. 
tions-that is, they are photomicrographs-and have not been retouched in any manner. Figure 12 shows a transverse section of the wood of the large redwood trunk that has been so often mentioned (see title page). The section is cut through one of the growth rings, which consists of 12 or 15 rows of very thick-walled cells. The large, regular thin-walled cells, which begin abruptly above the growth ring, belong to the spring wood-that is, the wood first formed after growth starts in spring, when the supply of nourishment is abundant. If there is sufficient moisture and all conditions are favorable this vigorous growth of wood cells may continue without interruption until the approach of cold or dry weather, but not infrequently there may be a brief shortage of moisture, and this is reflected in the formation of a few rows of thicker-walled cells. Such a condition may be observed in the present specimen, in which a slight, partial ring may be seen at some distance above the main ring.

The very perfect preservation of the wood of one of the pines (Pityoxylon amethystinum) is shown in figure 13, a view of a section cut through a part of a growth ring and into the spring and summer wood, the rings in this species being so broad that it is impossible to show a complete one. The opening near the bottom of the figure shows one of the large resin ducts, which, in the living wood, is filled with the "pitch" that so readily exudes when a branch is cut or broken. A longitudinal section of the other species of pine (Pityoxylon aldersoni) is shown in figure 14. The many little rows of superimposed cells in the midst of the long wood cells are the cutoff ends of what are known as medullary rays - that is, the little plates of cells that connect pith and bark. One of the resin cells cut in the long direction is shown near the center of the figure; the contents are much clarker than that of the wood cells.

The very great difference between the sections of coniferous wood just described and the wood of a deciduous tree is brought out in figure 15, which is a longitudinal section of a laurel (Laurinoxylon pulchrum). In this the wood cells are relatively much smaller and shorter, and the medullary rays are in several irregular rows. The large dotted duct near the middle of the figure is a feature not present in coniferous trees.

\section{SPECIES REPRESENTED.}

An enumeration of the kinds of trees that are represented by the woods in the fossil forests of the Yellowstone National Park will naturally be demanded. A superficial or macroscopic examination of these trunks would not permit a close decision as to the kind of wood; in fact, it would hardly be possible to do more than separate them by this means into coniferous and dicotyledonous trees. But by study- 
ing thin sections under the microscope it is possible to distinguish the different kinds with reasonable accuracy. As the result of such study the following species have been detected:
Magnificent redwood (Sequoia magnifica).
Alderson's pine (Pityoxylon aldersoni).
Amethyst pine (Pityoxylon amethystinums).
Laurel (Laurinoxylon pulchrum).
Aromatic bay (Perseoxylon aronaticum).
Hayden's sycamore (Plataninium haydeni).
Knowlton's sycamore (Plantaninium knowltoni).
Felix's buckthorn (Rhamnacinium radiatum).
Lamar oak (Quercinium lamarense).
Knowlton's oak (Quercinium knowltoni).

Although only three kinds of coniferous trees have thus far been found in the fossil forests of the park, fully 95 per cent of all the trunks belong to these three species. The preponderance of conifers is probably due to the facts that they were presumably more abundant in the beginning, and that, in general, coniferous wood decays less rapidly than that of most of deciduous-leaved trees. But the conditions were so favorable for preserving any wood that it is perhaps strange that not more trunks of deciduous-leared trees have been found there. As it is, however, a greater number are known from the park than from any other region. Thus, the Arizona fossil forests embraced only two species of deciduous-leared trees; the Calistoga (California) wood only one species, and the forest at Cairo, Egypt, only four species.

The 10 species of trees represented in the fossil forests of the park are by no means the only fossil plants that have been found. The finegrained ashes and volcanic mud in which the forests were entombed contain also great numbers of impressions of plants, many of them very perfectly preserved. Most of these are impressions of foliage, such as fronds and leaves, but they include also roots, stems, branches, fruiting organs, and even what is believed to be the petals of a large magnolia flower. About 150 different kinds of fossil plants have been found in the park, 80 in the same beds with the forests, and most of the others in slightly higher and younger beds. The list embraces 10 ferns, among them a fine chain fern (Woodwardia), several aspleniums, and a beautiful little climbing fern (Lygodium). The horse-tails (Equisetum) are represented by 4 species. The conifers include no less than 6 species of pines (Pinus), a yew (Taxodium), and 2 sequoias. These have been identified either from the foliage or the cones, and it is more than likely that some of the specimens may represent organs that belonged to trees represented by the fossil trunks, but as they have never been found connected they have been described separately. The monocotyledons, or plants with parallel-reined leaves, are represented by only a few forms, 
such as a single large grass (Phragmites), a few sedges (Cyperacites), a smilax, and a curious broad-leaved banana-like plant (Musophyllum). The dicotyledons, or deciduous-leaved plants, make up the bulk of the flora and include walnuts (Juglans), hickory nuts (Hicoria), bay berries( Myrica), poplars (Populus), willows (Salix), birches (Betula), hazel nuts (Corylus), beech nuts (Fagus), chestnuts (Castanea), oaks (Quercus), elms (Ulmus), figs (Ficus), breadfruits (Artocarpus), magnolias (Magnolia), laurels (Laurus), bays (Persea), cinnamons (Cinnamomum), sycamores (Plantanus), acacias (Acacia), sumachs (Rhus), bittersweet (Celastrus), maples (Acer), soap berries (Sapindus), buckthorns (Rhammus), grapes (Cissus), basswood (Tilia), aralias (Aralia), dogwoods (Cornus), persimmons (Diospyros), ash (Fraxinus), and a number of others without vernacular names.

\section{COIMPARISON WITH LIVING FORESTS.}

A brief comparison of the fossil forests with the forests now living in the Yellowstone National Park may be of some interest. The present forests are prevailingly coniferous, the most abundant and widely distributed tree being the lodgepole pine (Pinus murrayana), which forms dense forests over much of the plateau region. It is distinguished by having the leaves in clusters of two. It is a tree with a slender trunk, usually 70 or 80 feet high, though in exceptionally favorable localities it may reach a height of 150 feet. Its diameter rarely exceeds 2 or 3 feet. The areas ravaged by forest fires are usually reforested by this pine alone, and the young trees come up so close together as to form thickets that can scarcely be penetrated.

There are two other pines in the park, both white pines, allied to the common white pine of the Eastern States, and like it both have the leaves in clusters of 5 . One, known as the Rocky Mountain white pine (Pinus flexilis) is a small tree, only 40 or 50 feet in height, and usually grows singly or in small groves. The other, called the Western white pine (Pinus albicaulis), is still smaller, being usually 20 to 30 feet high, and has a short trunk some 2 to 4 feet in diameter. It grows on high slopes and exposed ridges.

Perhaps next in abundance to the lodgepole pine is the white or Engelmann spruce (Picea engelmanni), a tall, handsome tree with disagreeable smelling foliage. Another rather abundant tree is the Douglas spruce, or red fir (Pseudotsuga mucronata), which, where best developed on the Pacific coast, attains a height of 200 feet. though in the drier interior it is rarely over 80 or 100 feet high. There are also two species of fir, the white fir (Abies grandis) and the Balsam fir (Abies lasiocarpa), and a single juniper (Juniperus communis siberica), which is often scarcely more than a shrub. 
The deciduous-leared trees are almost a negligible element in the present park flora, being confined to an occasional cottonwood (Populus angustifolia) at the lower elevations, along the Yellowstone River, and small groves of the quaking aspen (Populus tremuloides). Along the streams and in wet places there are many species of willow (Salix) and several alders (Alnus), and in mountain bogs and valleys there is a small birch (Betula glandulosa). There are, of course, many small shrubs, such as gooseberries, currants, and roses.

\section{AGE OF THE FOSSIL FORESTS.}

The question is often asked, How old are the fossil forests? It is, of course, impossible to fix their age exactly in years, though it is easy enough to place them in the geologic time scale. The stratified rocks that make up the crust of the earth, from the oldest we know to the most recent, have been divided by geologists into a number of major divisions or systems, each-except perhaps the oldestcontaining the remains of certain kinds of plants and animals. The accompanying diagram (fig. 16), shows these major time divisions, arranged in their proper sequence from the lowest to the highest. The star $(*)$ in this geologic time scale indicates the age of the rocks in which the fossil forests were entombed. It shows that they were buried during the Tertiary period. This period is divided into four epochs, the oldest called Eocene, having been succeeded in turn by the Oligocene, the Miocene, and the Pliocene, which just precedes the Pleistocene or glacial epoch. The forests of the Yellowstone National Park are found in the Miocene series of the Tertiary. As compared with the eons of geologic time that preceded it the Miocene is relatively very recent, though, if the various estimates of the age of the earth that have been made by geologists are anywhere near correct it may well have been a million years ago. It must be remembered, however, that this estimate involves more or less speculation based on a number of factors which may or may not have been correctly interpreted.

A study of the fossil trees themselves gives at least a rough approximation as to the length of time it may have taken to accumulate the beds in which they are now buried. As already mentioned, there is a succession of forests, one above another, through a thickness of 2,000 feet of strata. The unit of the measure of the time is the time taken by each forest to grow. Pine trees of the types represented in the fossil trunks require 200 or 300 years to reach maturity, and redwoods may require from 500 to 1,000 years. Twelve or more of these forest levels have been found. By multiplying this number by the minimum age of the trees (200 years) we shall have 2,400 years, and by multiplying it by the maximum age of the redwood 
(1,000 years) we shall have 12,000 years as the possible time during which these forests flourished. It is possible that the truth lies somewhere between these extremes.

\begin{tabular}{|c|c|c|}
\hline Era. & Period. & Epoch. \\
\hline \multirow{6}{*}{ Cenozoic. } & \multirow{2}{*}{ Quaternar } & Recent. \\
\hline & & Pleistocene (glacial). \\
\hline & \multirow{4}{*}{ *Tertiary. } & Pliocene. \\
\hline & & *Miocene. \\
\hline & & Oligocene. \\
\hline & & Eocene. \\
\hline \multirow{3}{*}{ Mesozoic. } & Cretaceous. & \\
\hline & Jurassic. & \\
\hline & Triassic. & \\
\hline \multirow{5}{*}{ Paleozoic. } & Carboniferous. & \\
\hline & Deronian. & \\
\hline & Silurian. & \\
\hline & Ordovician. & \\
\hline & Cambrian. & \\
\hline \multirow{2}{*}{$\begin{array}{l}\text { Protero- } \\
\text { zoic. }\end{array}$} & Algonkian. & \\
\hline & Archean. & \\
\hline
\end{tabular}

Fig. 16.-Geologic Divisions.

\section{CLIMATE DURING THE LIFE OF THE FOSSIL TREES.}

$\Lambda$ final word may be added regarding the probable climate of the region during the lifetime of these fossil forests. It is obvious that the present flora of the Yellowstone National Park has comparatively little relation to the Tertiary flora and can not be considered the descendant of it. It is also clear that the climatic conditions must have greatly changed since Tertiary time. The Tertiary flora appears to have come from the south, but the present flora is evidently of more northern origin. 'The climate during Tertiary time, as indicated by the regetation, was temperate or warm-temperate, not unlike that of Virginia or the Carolinas at the present time, and the 
presence of numerous species of figs, a supposed bread-fruit tree, cinnamons, bays, and other southern plants indicates that it may have been almost subtropical. However, the conditions that were favorable to this seemingly subtropical growth may have been different from the conditions now necessary for the growth of similar vegetation. It may be that these supposed subtropical plants were at that time so constituted as to grow in a temperate land, and that they may have become tropical in recent times. Following this general line of thought it may be said that although the Tertiary vegetation of the Yellowstone National Park would now be regarded as indicating a temperate or even warmer climate, the actual climate may not have been subtropical. It is certain, however, that the conditions were very different from those now prevailing in the park. 


\section{PUBLICATIONS ON YELLOWSTONE NATIONAL PARK.}

DISTRIBUTED FREE HY THE NATIONAL PARK SERVICE,

The following publication may be obtained free on written application to the Director of the National Park Service:

Rules and Regulations, Yellowstone National Park (issued yearly). 'l'his pamphlet contains general information of interest to the tourist.

SOLD BY THE SUPERINTENDENT OF DOCUMENTS. ${ }^{1}$

The following publications may be obtained from the Superintendent of Documents, Government Printing Office, Washington, D. C., at the prices given. Remittances should be made by money order or in cash :

National I'ark Portfolio, by Robert Sterling Yart. 248 pages, includiug 306 illustrations. Bound securely in cloth, $\$ 1$.

Contains nine chapters, each descriptive of a national park and one larger chapters devoted to other national parks and monuments.

(feological History of Yellowstone National Park, by Armold Hague, "2., lages, including 10 illustrations, 10 cents.

This pamphlet contains a general résumé of the geologic forces that have been active in the Yellowstone National Park.

Geysers of the Yellowstone National Park, by Walter Harvey Weed, :32 1)ages, including 23 illustrations, 10 cents.

In this pamphlet is a description of the forces which have produced the geysers, and the geysers of the Yellowstone are compared with those in Iceland and New Zealand.

Fossil Forests of the Yellowstone National Park, by F. H. Knowlton, 30 pages, including 15 illustrations, 10 cents. (This publication.)

This pamphlet contains descriptions of the fossil forests of the Yellowstone National Park and an account of their origin.

Fishes of the Yellowstone National Park, by W. C. Kendall (Bureau of Fisheries Document 818.) 28 pages, including 17 illustrations, 5 cents.

Contains descriptions of the species and lists of streams where found.

\section{MAP.}

I topographic map of the park may be purchased from the Director of the Creological Survey, Washington, D. C., at the price given. Remittances should be made by cash or money order.

Map of Yellowstone National Park, size $28 \frac{1}{2}$ by 32 inches; scale, 2 miles to the inch. Price, 25 cents.

The roads, trails, and names are put in black, the streams and lakes in blue, and the relief is indicated by brown contour lines.

1 May be purchased by personal application at the information office in the park, at Mammoth IIot Springs, but that office can not fill mail orders. 

